\title{
UPDATE ON BREEDING FOR RESISTANCE TO SUNFLOWER BROOMRAPE
}

Fernández-Martínez, J.M. ${ }^{*}$, Domínguez, J. ${ }^{2}$, Pérez-Vich, B. ${ }^{1}$ and Velasco, L. ${ }^{1}$

${ }^{1}$ Institute for Sustainable Agriculture (CSIC). Alameda del Obispo s/n. Apartado 4084, E-14080 Córdoba, Spain

${ }^{2}$ CIFA “Alameda del Obispo", IFAPA-CICE, Junta de Andalucía, Córdoba, Spain

Received: February 12, 2008 Accepted: May 25, 2008

\section{SUMMARY}

Sunflower broomrape (Orobanche cumana Wallr.) is currently regarded as one of the most important constraints in sunflower (Helianthus annuus L.) production. In the last fifteen years, efforts to introduce genetic sources of resistance to this parasite in sunflower hybrids were followed by the occurrence of new virulent races that promptly overcame all known resistance genes. Due to this situation, most of the research efforts have focused on the development and characterization of new sources of genetic resistance to the most virulent races and also on the genetic structure and variability of $O$. cumana populations and their evolution, in order to develop long-term strategies for sunflower broomrape management. Results of evaluation of sunflower germplasm for resistance to different broomrape races have demonstrated that wild Helianthus species constitute the major reservoir of genes conferring resistance to new virulent races. Cultivated germplasms are also valuable sources of resistance genes. Most of the resistant sources have been found to be controlled by major genes, although quantitative resistance and epistatic effects have also been reported. Different dominance reactions, depending on the race of broomrape, the source of resistance and the susceptible parental line used for crossing have been observed. Molecular studies have shown that phenotypic variance for race E resistance was mainly explained by a major QTL associated to the resistance or susceptibility character, while race $F$ resistance was explained by several QTL with a small to moderate effect, mainly associated with the number of broomrapes per plant, suggesting the existence of a quantitative component in the resistance to race $F$. The relevance of these findings for sunflower breeding for resistance to broomrape is discussed.

Key words: Orobanche cumana, broomrape races, genetic resistance, inheritance

* Corresponding author: Phone: +34 957 499204; Fax: +34 957 499252;

e-mail: cs9femaj@uco.es 


\section{INTRODUCTION}

Sunflower broomrape (Orobanche cumana Wallr.) is an obligate, holoparasitic angiosperm that lives attached to the roots of sunflower (Helianthus annuus L.), depleting them of nutrients and water. This parasitic plant is currently regarded as one of the most important constraints for sunflower production in Southern Europe, the Black Sea region, Ukraine and China (Parker, 1994). Broomrape attacks are frequently severe and yield losses can reach up to 50\% (Domínguez, 1996a). Control of this parasite remains extremely difficult, as thousands of tiny seeds produced by a single broomrape plant can be easily dispersed by wind, water, animals, humans, machinery or attached to sunflower seeds. Broomrape seeds may remain viable for 15-20 years and will only germinate in the presence of the host plant (Škorić, 1988). Although use of herbicides is being considered as a promising control measure, at present genetic resistance offers the most effective and feasible control against $O$. cumana. However, the introduction of new resistance sources has been frequently followed by the occurrence of new pathogenic races overcoming the resistance, which determines the need for additional sources of resistance.

In a classic study, Vrânceanu et al. (1980) identified five pathogenic races, named A through $\mathrm{E}$, with a set of sunflower differentials carrying the dominant resistance genes Or1 through Or5, that provide an accumulative resistance to the five successive races. In 1995, a new race $\mathrm{F}$, overcoming all the known resistance genes, Or 1 through Or5, was identified in Spain and it spread rapidly (Alonso et al., 1996; Dominguez, 1999). Resistance to this new race was found in germplasm of both cultivated and wild sunflower (Sukno et al., 1999; Fernández-Martínez et al., 2000; Rodríguez-Ojeda et al., 2001). However, a more virulent race (designated race $\mathrm{G}$ ), attacking the cultivars resistant to race $\mathrm{F}$, has been recently identified (Molinero-Ruiz and Melero-Vara, 2005). Virulent races overcoming the resistance gene Or5 were also identified in Romania in 1996 (Pacureanu et al., 2004) and in Turkey, where the new races seem to be more virulent than the races present in other countries (Kaya et al., 2004).

\section{SOURCES OF RESISTANCE}

The sources of resistance to Orobanche races found in the early sunflower breeding work in the former USSR originated from land races of cultivated sunflowers, but genetic resistance was also introduced into susceptible sunflower from wild species, mainly H. tuberosus (Pustovoit, 1966). Cultivated material tracing back to early USSR cultivars and $H$. tuberosus were also important sources of resistance for the O. cernua/cumana complex of races in Romania (Vrânceanu et al., 1980). Sources of resistance to recent virulent races have been scant in cultivated germplasm. Gulya et al. (1994) found only 22 resistant entries in a field evaluation of 903 accessions in Turkey. Domínguez et al. (1996) found only 8 resistant and 33 
Table 1: Disease reaction of annual and perennial species to broomrape race $\mathrm{F}$

\begin{tabular}{|c|c|c|c|}
\hline Species & Num. of entries & Incidence $^{1}$ & $\mathrm{DS}^{2}$ \\
\hline \multicolumn{4}{|l|}{ Annual species } \\
\hline H. agrestis & 1 & 0 & 0 \\
\hline H. annnuus & 1 & 100 & 12.5 \\
\hline H. anomalus & 1 & 0 & 0 \\
\hline H. argophylus & 1 & 100 & 2.1 \\
\hline H. debilis (several subsp.) & 3 & $0-35$ & $0-1.6$ \\
\hline H. deserticota & 1 & 100 & 5.0 \\
\hline H. exilis & 1 & $0-42$ & $0-3.2$ \\
\hline H. petiolaris & 1 & 100 & 4.5 \\
\hline H. praecox & 1 & 100 & 2.3 \\
\hline \multicolumn{4}{|l|}{ Diploid perennials $(2 n=34)$} \\
\hline H. atrorubens & 2 & 0 & 0 \\
\hline H. decapetalus & 2 & 0 & 0 \\
\hline H. divaricatus & 3 & $0-10$ & $0-1$ \\
\hline H. giganteus & 1 & 0 & 0 \\
\hline H. glaucophylus & 1 & 0 & 0 \\
\hline H. gracilentus & 1 & 0 & 0 \\
\hline H. grosseserratus & 5 & 0 & 0 \\
\hline H. maximiliani & 5 & $0-80$ & $0-3$ \\
\hline H. microcephalus & 1 & 0 & 0 \\
\hline H. nuttallii (4 subsp.) & 6 & 0 & 0 \\
\hline H. salicifolius & 1 & 0 & 0 \\
\hline H. smithii & 1 & 0 & 0 \\
\hline \multicolumn{4}{|l|}{ Tetraploid perennials $(2 n=68)$} \\
\hline H. hirsutus & 1 & 0 & 0 \\
\hline H. laevigatus & 1 & 0 & 0 \\
\hline H. pumilus & 1 & 0 & 0 \\
\hline H. strumosus & 3 & 0 & 0 \\
\hline \multicolumn{4}{|l|}{ Hexaploid perennials $(2 n=102)$} \\
\hline H. californicus & 1 & 0 & 0 \\
\hline H. ciliaris & 1 & 0 & 0 \\
\hline H. xlaetiflorus & 1 & 0 & 0 \\
\hline \multicolumn{4}{|l|}{ H. pauciflorus } \\
\hline subsp. pauciflorus & 2 & $0-10$ & $0-1$ \\
\hline subsp. subrhomboideus & 2 & 0 & 0 \\
\hline H. tuberosus & 3 & 0 & 0 \\
\hline \multicolumn{4}{|l|}{ Cultivated checks } \\
\hline P-1380 (Or5) & - & 100 & 5.6 \\
\hline $\mathrm{P}-21$ & - & 100 & 18.2 \\
\hline
\end{tabular}


segregating entries in the evaluation of 429 accessions of different origins for resistance to race $\mathrm{E}$, carried out in Spain under controlled conditions. In a more recent evaluation, only 4 entries out of 55 cultivated accessions, previously reported as resistant in Turkey (Gulya et al., 1994), were found resistant against the race $F$ pathotypes predominant in Spain (Fernández-Martínez et al., 2000). In contrast, a high level of resistance to races $\mathrm{E}$ and $\mathrm{F}$ has been found in the evaluation of wild Helianthus species. In Spain, Ruso et al. (1996) and Fernández-Martínez et al. (2000) found resistance to several virulent races, including race $\mathrm{F}$, in 29 perennial wild species. The annual species showed a much lower level of resistance, with only four out of 18 evaluated entries showing resistance to race F (Fernández-Martínez et al., 2000). Resistance to O. cumana has also been identified in wild Helianthus species in other countries (Pogorletsky and Geshele, 1976; Christov et al., 1996; Škorić, 1988). All these evaluations demonstrated that wild Helianthus species constitute the major reservoir of genes controlling resistance to the new virulent races. Results of evaluation of wild species for resistance to the virulent race $\mathrm{F}$ are summarized in Table 1.

In general, transferring broomrape resistance genes from wild annual species into cultivated lines can be accomplished rather easily with a conventional crossing and backcrossing scheme. Conversely, crossing perennial Helianthus species with the cultivated sunflower is generally difficult due to early hybrid embryo abortion as well as high levels of sterility in the $\mathrm{F}_{1}$ or $\mathrm{BC}_{1}$ generations. These problems can be overcome with the utilization of the embryo culture technique, chromosome doubling of the $F_{1}$ and the creation of amphiploids (Jan and Fernández-Martínez, 2002). Using these techniques, amphiploids of the perennial wild species $H$. grosseserratus, $H$. maximiliani and $H$. divaricatus, resistant to race $\mathrm{F}$, were produced and used as a bridge to transfer the resistance to cultivated sunflower (Jan and Fernández-Martínez, 2002). As a result, four germplasm populations named BR1 through BR4, resistant to race F, were developed and released (Jan et al., 2002).

Table 2: Released lines resistant to broomrape race $\mathrm{F}$

\begin{tabular}{|c|c|c|c|}
\hline $\begin{array}{l}\text { Resistant } \\
\text { line }\end{array}$ & PI number & Origin & Pedigree $^{1}$ \\
\hline$\overline{\text { BR1 }}$ & PI 617026 & Wild species (H. grossesserratus) & P-21//H. gro.-001/P21 (PD)/3/ HA89 \\
\hline BR2 & PI 617027 & Wild species $(H$. maximiliani) & H. max.-004/P-21(D)// P21/3/ HA89 \\
\hline BR3 & PI 617028 & Wild species (H. divaricatus) & H. div.-830/P-21(D)// P21/3/ HA89 \\
\hline BR4 & PI 617026 & $\begin{array}{l}\text { Wild species }(H . \text { grossesserratus } \\
\text { and H.divaricatus) }\end{array}$ & $\begin{array}{l}\text { H.div.-830/P-21(D) // H.gro-001/P21(D)/ } \\
\text { 3/ P-21/4/HA89 }\end{array}$ \\
\hline P96 & PI 633612 & Cultivated sunflower & KREM-94-8 (Yugoslavia) \\
\hline K-96 & PI 633613 & Cultivated sunflower & PER-94-5 (Yugoslavia) \\
\hline R-96 & PI 633614 & Cultivated sunflower & ROD-94-15 (Yugoslavia) \\
\hline L-86 & PI 633615 & Cultivated sunflower & Ames 3377 (VIR-115) \\
\hline AM-1 & PI 641057 & Cultivated sunflower & VNIIMK 6540 (Russia) \\
\hline AM-2 & PI 641058 & Cultivated sunflower & Romsun V-1352 (Romania) \\
\hline AM-3 & PI 641059 & Cultivated sunflower & VIR 101 (Russia) \\
\hline
\end{tabular}

TJan et al. (2002); Fernández-Martínez et al. (2004); Pérez-Vich et al. (2005). 
Although a higher frequency of resistance has been observed in wild sunflower species, some resistance to the new virulent races has also been found in cultivated germplasm, especially in material tracing back to old Russian cultivars. From this material, four lines uniformly resistant to races $\mathrm{B}, \mathrm{E}$ and $\mathrm{F}$ and susceptible or showing segregation for race G (Fernández-Martínez et al., 2004) and three lines showing quantitative resistance to race F (Pérez-Vich et al., 2005) were developed. Resistance to broomrape races $\mathrm{F}$ and $\mathrm{G}$ has also been reported by several seed companies. A list of released lines resistant to race $\mathrm{F}$ from wild and cultivated origin is given in Table 2 .

\section{GENETICS OF SUNFLOWER RESISTANCE TO Orobanche AND STRATEGIES OF BREEDING FOR RESISTANCE}

The host-parasite system of sunflower-O. cumana described for races A through E appears to follow the gene-for-gene model. Vrânceanu et al. (1980) established a set of five sunflower differentials carrying five dominant resistant genes, Or1 through Or5, each providing resistance to a new race and also to the previous ones. Genetic studies carried out by other authors agreed with monogenic and dominant inheritance of resistance to sunflower broomrape (Pogorletsky and Geshele, 1976; Ish-Shalom-Gordon et al., 1993; Sukno et al., 1999), although two dominant genes (Dominguez, 1996b) and one recessive gene (Ramaiah, 1987) have also been reported. Genetic resistance to race F in the germplasm sources P-96 and KI-534, derived from cultivated sunflower, was found to be controlled by recessive alleles at two loci (Rodríguez-Ojeda et al., 2001; Akhtouch et al., 2002). These recessive genes also controlled resistance to race $\mathrm{E}$ in the case of KI-534 (Rodríguez-Ojeda et al., 2001), while resistance to race E in P-96 was conferred by the dominant gene Or5 (Pérez-Vich et al., 2004b).

In contrast to the resistance derived from cultivated sources, the race $\mathrm{F}$ resistant population BR4, derived from wild species, was found to be under the control of a single dominant gene designated Or6 (Perez-Vich et al., 2002). Pacureanu et al. (2004) reported also a single dominant gene controlling the resistance to race $\mathrm{F}$ in Romania. However, the results of the evaluation of crosses between different race $F$ resistant lines and different susceptible parental lines have shown that dominance relationships and genetic control of broomrape resistance in sunflower is highly dependent on the race of broomrape, the source of resistance, and also the susceptible parental line used for the cross (Pérez-Vich et al., 2004a). For example, $\mathrm{F}_{1}$ hybrids segregating for resistance and deviations from the monogenic inheritance previously reported by Pérez-Vich et al. (2002) were observed in some crosses between the race $\mathrm{F}$ resistant line $\mathrm{J} 1$ and susceptible lines (Velasco et al., 2006). This indicated incomplete dominance of the Or6 alleles and the presence of a second gene, Or7, whose expression appeared to be environmentally dependent. Even though gene nomenclature Or6 and Or7 has been utilized in several different stud- 
ies to designate genes that confer resistance to broomrape races superior to race $\mathrm{E}$, no comparative research has been conducted and probably different loci/alleles are being reported by different authors under the same designation. A summary of different inheritance studies on broomrape resistance is given in Table 3.

Table 3: Inheritance of broomrape resistance in sunflower

\begin{tabular}{|c|c|c|c|c|}
\hline $\begin{array}{l}\text { Resistance } \\
\text { source }\end{array}$ & Race tested & Gene & Gene action & References \\
\hline Kruglik-A-41 & A-E & Or1 & Single, dominant & Vrânceanu et al. (1980) \\
\hline Jdanov 8281 & A-E & Or2 & Single, dominant & Vrânceanu et al. (1980) \\
\hline Record & $A-E$ & Or3 & Single, dominant & Vrânceanu et al. (1980) \\
\hline S-1358 & $A-E$ & Or4 & Single, dominant & Vrânceanu et al. (1980) \\
\hline P-1380 & $A-E$ & Or5 & Single, dominant & Vrânceanu et al. (1980) \\
\hline SW501 & Unknown & Unknown & Single, dominant & Ish-Shalom-Gordon et al. (1993) \\
\hline NR-5 & $E$ & Or5 & Single, dominant & Sukno et al. (1999) \\
\hline $\mathrm{R}-41$ & $E$ & Unknown & Two dominant genes & Dominguez (1996b) \\
\hline P-96 & $\begin{array}{l}\text { F (Mencia) } \\
\text { (Spain) }\end{array}$ & or6, or7 & Two recessive genes & Akhtouch et al. (2002) \\
\hline P-96 & $E$ & Or5 & Single, dominant & Pérez-Vich et al. (2004b) \\
\hline $\mathrm{Kl}-534$ & $E$ & or6, or $7^{1}$ & Two recessive genes & Rodríguez-Ojeda et al. (2001) \\
\hline $\mathrm{KI}-534$ & $\begin{array}{c}\text { F (EK23) } \\
\text { (Spain) }\end{array}$ & or6, or7 & Two recessive genes & Rodríguez-Ojeda et al. (2001) \\
\hline J1 (BR-4) & $\begin{array}{l}\text { F (Mencia) } \\
\text { (Spain) }\end{array}$ & Or6 & Single, dominant & Pérez-Vich et al. (2002) \\
\hline LC-1093 & F (Romania) & Or6 & Single, dominant & Pacureanu et al. (2004) \\
\hline J1 (BR-4) & $\begin{array}{l}\mathrm{F} \text { (Mencia) } \\
\text { (Spain) }\end{array}$ & Or6, Or7 & $\begin{array}{l}\text { Two partially } \\
\text { dominant genes }\end{array}$ & Velasco et al. (2006) \\
\hline
\end{tabular}

${ }^{T}$ The nomenclature Or6 and Or7 has been utilized by several authors, although no comparative studies have been conducted to test whether they correspond to the same loci/alleles.

The development of broomrape resistant inbred lines is not an easy task, mainly because of the large difficulties to assess resistance in experimental conditions, where the existence of escapes, genetic background effects, and genotype $\mathrm{x}$ environment interactions lead to a sometimes inefficient selection. Molecular studies aimed to map genes conferring resistance to races $\mathrm{E}$ and $\mathrm{F}$ have been carried out. The Or5 gene conferring resistance to race $\mathrm{E}$ has been mapped to a telomeric region of linkage group (LG) 3 of the sunflower genetic map (Lu et al., 2000; Tang et al., 2003; Pérez-Vich et al., 2004b) (Figure 1). Quantitative trait loci (QTL) analyses showed that phenotypic variance for race $\mathrm{E}$ resistance was mainly explained by a major QTL, corresponding to the Or5 gene, associated to the resistance or susceptibility character, whereas race $\mathrm{F}$ resistance was explained by several QTL with small to moderate effects, mainly associated with the number of broomrape stalks per plant (Pérez-Vich et al., 2004b). These results suggested that resistance to broomrape in sunflower is controlled by a combination of a qualitative, race-specific resistance component affecting the presence or absence of broomrape, and a 
quantitative, non-race specific resistance component affecting the number of broomrape stalks per plant.

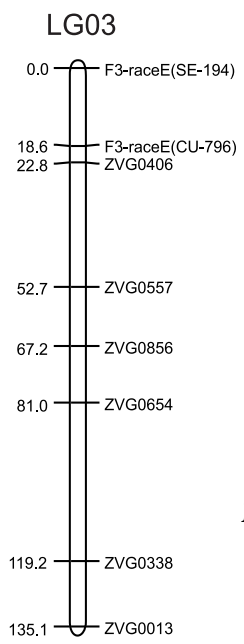

Figure 1: Molecular map of linkage group three of sunflower containing the scores for race $E$ (populations $\mathrm{SE}-194$ and CU-796) of broomrape in phenotypic evaluations of $F_{3}$ populations from the cross P-21 × P-96 (Pérez-Vich et al., 2004b).

One important aspect in breeding for resistance to Orobanche is the study of the mechanisms involved in the resistance. As mentioned above, the use of resistant cultivars, usually monogenic in nature, has been followed by the occurrence of new, more virulent races of the parasite that overcome the existing sources of resistance. Therefore an effective breeding strategy to achieve a more effective and durable resistance semms to include a combination of several resistance mechanisms in one genotype. Several groups of mechanisms of resistance to Orobanche have been described (reviewed by Alonso, 1998):

- Deficient production of germination stimulants released by the roots of the host plant;

- Mechanical or chemical barriers preventing haustorium penetration of the host root (lignification or hypersensitive-like reaction);

- Accumulation of toxic compounds that slow down the growth of tubercles and the connection to the host vascular system.

Resistance mechanisms were proposed in early studies on resistance to sunflower broomrape. Resistance based on mechanical barriers was reported by Pustovoit (1966), who proposed that resistance was produced by the formation of a callus through swelling of the roots. The action of peroxidases excreted by the parasite was suggested to be involved in the lignification of host cells (Antonova, 1978). Differences in peroxidase production were suggested as an explanation of the different virulence of races A and B as well as an explanation of the gene-for-gene interaction in the sunflower O. cernua/cumana system (Antonova and Ter Borg, 1996). Different resistance mechanisms have been described for differential lines resistant to several races. For example, the mechanism of resistance of the cultivar Jdanov 8281 , carrying the Or2 gene, was reported to include a hypersensitive-like reaction 
(Antonova and Ter Borg, 1996), while the accumulation of phenolic compounds in damaged cells and lignin formation in sunflower vessels were reported to be involved in the resistance controlled by the gene Or3 (Tolmachev, 1991). More recently, Labrousse el al. (2001) and Echevarría-Zomeño et al. (2006) compared resistant and susceptible sunflower genotypes and identified several resistance mechanisms such as reduced stimulation of broomrape seed germination, suberization and protein cross-linking in the cell wall in contact with the parasite, and secretion of phenolic compounds that poisoned the parasite.

\section{CONCLUSIONS AND FUTURE PROSPECTS}

The rapid evolution of $O$. cumana populations leading to the occurrence of new virulent races requires a continuous search for new resistance sources. Results of evaluation of sunflower germplasm for resistance to different races have demonstrated that wild Helianthus species constitute the major source of resistance genes conferring resistance to new virulent races, but cultivated germplasms are also valuable sources of resistance. Most of the resistant sources have been found to be controlled by major genes (vertical resistance), although quantitative (horizontal) resistance has also been reported. Race-specific dominant genes are considered an ideal source of resistance for single-cross hybrid breeding by seed companies, because they only need to be incorporated into one of the parents. However, the combination of vertical and horizontal resistance mechanisms on the same genotype could contribute to the development of a more durable resistance. Molecular marker studies to identify QTL associated with broomrape resistance genes are increasingly contributing to clarification of the genetic control of broomrape resistance in sunflower, facilitating the pyramiding of different resistance genes, and speeding up the development of resistant inbred lines though marker-assisted selection.

\section{REFERENCES}

Akhtouch, B., Muñoz-Ruz, J., Melero-Vara, J.M., Fernández-Martínez, J.M. and Domínguez, J., 2002. Inheritance of resistance to race F of broomrape (Orobanche cumana Wallr.) in sunflower lines of different origin. Plant Breed. 121: 266-269.

Alonso, L.C., 1998. Resistance to Orobanche and resistance breeding: A review. In: K. Wergman, L.J. Musselman and D.M. Joel (Eds). Current problems of Orobanche research. Proc. $4^{\text {th }}$ Int. Symp. Orobanche. Albena, Bulgaria, 23-26 September 1998. pp. 233-237.

Alonso, L.C., Fernández-Escobar, J., López, G., Rodríguez-Ojeda, M. and Sallago, F., 1996. New highly virulent sunflower broomrape (Orobanche cernua Loefl.) pathotype in Spain. In: M. Moreno, J. Cubero, D. Berner, D. Joel, L. Musselman, and C. Parker (Eds), Advances in Parasitic Plant Research. Proc. $6^{\text {th }}$ Int. Symp. Parasitic Weeds. Córdoba, Spain, 16-18 April 1996. pp. 639-644.

Antonova, T.S., 1978. Development of broomrape (O. cumana Wallr.) haustoria in roots of resistant and susceptible forms of sunflower. Bot. J. 7: 1025-1029.

Antonova, T.S. and Ter Borg, S.J., 1996. The role of peroxidase in the resistance of sunflower against Orobanche cumana in Russia. Weed Res. 36: 113-121. 
Christov, M., Shindrova, P., Encheva, J., Venkov, V., Nikolova, L., Piskov, A., Petrov, P. and Nikolova, V., 1996. Development of fertility restorer lines originating from interspecific hybrids of genus Helianthus. Helia 19: 65-72.

Domínguez, J., 1996a. Estimating effects on yield and other agronomic parameters in sunflower hybrids infested with the new races of sunflower broomrape. p. 118-123. In: Proc. Symposium on Disease Tolerance in Sunflower, Beijing, China, International Sunflower Association, Paris.

Domínguez, J., 1996b. R-41, a sunflower restorer inbred line, carrying two genes for resistance against a highly virulent Spanish population of Orobanche cernua. Plant Breed. 115: 203-204.

Domínguez, J., 1999. Inheritance of the resistance to Orobanche cumana Wallr. In: Cubero J.I. (Eds), Resistance to broomrape: The state of the art. Congresos y Jornadas 51/99. Junta de Andalucía. Consejería de Agricultura y Pesca, Seville, Spain. pp. 139-141.

Domínguez, J., Melero-Vara, J.M., Ruso, J., Miller, J. and Fernández-Martínez, J.M., 1996. Screening for resistance to broomrape (Orobanche cernua) in cultivated sunflower. Plant Breed. 115: 201-202.

Echevarría-Zomeño, S., Pérez-Luque, A., Jorrín, J. and Maldonado, A., 2006. Pre-haustorial resistance to broomrape (Orobanche cumana) in sunflower (Helianthus annuus): cytochemical studies. J. Exp. Bot. 57: 4189-4200.

Fernández-Martínez, J.M., Melero-Vara, J.M., Muñoz-Ruz, J., Ruso, J. and Domínguez, J., 2000. Selection of wild and cultivated sunflower for resistance to a new broomrape race that overcomes resistance to Or5 gene. Crop Sci. 40: 550-555.

Fernández-Martínez, J.M., Pérez-Vich, B., Akhtouch, B., Velasco, V., Muñoz-Ruz, J., MeleroVara, J.M. and Domínguez, J., 2004. Registration of four sunflower germplasms resistant to race $\mathrm{F}$ of broomrape. Crop Sci. 44: 1033-1034.

Gulya, T.J., Aydin, A. and Brothers, M., 1994. Evaluation of broomrape (Orobanche cumana) resistance in sunflower germplasm of the USDA Plant Introduction Collection. In: Proc. $16^{\text {th }}$ Sunflower Res. Workshop, Fargo, ND, USA, 13-14 January, 1994. Natl. Sunf. Assoc., Bismarck, ND, USA. pp. 53-55.

Ish-Shalom-Gordon, N., Jacobsohn, R. and Cohen, Y., 1993. Inheritance of resistance to Orobanche cumana in sunflower. Phytopathol. 83: 1250-1252.

Jan, C.C. and Fernández-Martínez, J.M., 2002. Interspecific hybridization, gene transfer, and the development of resistance to broomrape race F in Spain. Helia 36: 123-136.

Jan, C.C., Fernández-Martínez, J.M., Ruso, J. and Muñoz-Ruz, J., 2002. Registration of four sunflower germplasm populations resistant to broomrape race F. Crop Sci. 42: 22172218.

Kaya, Y., Evci, G., Pekcan, V. and Gucer, T., 2004. Determining new broomrape-infested areas, resistant lines and hybrids in Trakya region of Turkey. Helia 27: 211-218.

Labrousse, P., Arnaud, M.C., Serieys, H., Bervillé, A. and Thalouan, P., 2001. Several mechanisms are involved in resistance of Helianthus to Orobanche cumana Wallr. Ann. Bot. 88: 859-868.

Lu, Y.H., Melero-Vara, J.M., García-Tejada, J.A. and Blanchard, P., 2000. Development of SCAR markers linked to the gene Or5 conferring resistance to broomrape (Orobanche cumana Wallr.) in sunflower. Theor. Appl. Genet. 100: 625-632.

Molinero-Ruiz, M.L. and Melero-Vara, J.M., 2005. Virulence and aggressiveness of sunflower broomrape (Orobanche cumana) populations overcoming the Or5 gene. In: Seiler, G.J. (ed.), Proc. $16^{\text {th }}$ Int. Sunflower Conf., Fargo, ND, August 29-September 2, 2004 . Int. Sunflower Assoc., Paris. pp. 165-169.

Pacureanu, M., Veronesi, C., Raranciuc, S. and Stanciu, D., 2004. Parasite-Host plant interaction of Orobanche cumana Wall. (Orobanche cernua Loefl.) with Helianthus annuus. In: Seiler, G.J. (Ed.), Proc. $16^{\text {th }}$ Int. Sunflower Conf., Fargo, ND, August 29-September 2, 2004. Int. Sunflower Assoc., Paris. pp. 171-177.

Parker, C., 1994. The present state of problem. In: A.H. Pieterse, J.A.C. Verkleijand, and S.J. Ter Borg (Eds), Biology and management of Orobanche. Proc. $3^{\text {rd }}$. Int. Workshop on Orobanche and related Striga research, Royal Tropical Institute, Amsterdam. pp. 17-26.

Pérez-Vich, B., Akhtouch, B., Muñoz-Ruz, J., Fernández-Martínez, J.M. and Jan, C.C., 2002. Inheritance of resistance to a highly virulent race " $F$ " of Orobanche cumana Wallr. in a sunflower line derived from interspecific amphiploids. Helia 25: 137-144. 
Pérez-Vich, B., Aktouch, B., Mateos, A., Velasco, V., Jan, C.C., Fernández, J., Domínguez, J. and Fernández-Martínez, J.M., 2004a. Dominance relationships for genes conferring resistance to sunflower broomrape (Orobanche cumana Wallr.). Helia 27: 183-192.

Pérez-Vich, B., Akhtouch, B., Knapp, S.J., Leon, A.J., Velasco, V., Fernández-Martínez, J.M. and Berry, S.T., 2004b. Quantitative trait loci for broomrape (Orobanche cumana Wallr.) resistance. Theor. Appl. Genet. 109: 92-102.

Pérez-Vich, B., Velasco, V., Muñoz-Ruz, J., Domínguez, J. and Fernández-Martínez, J.M., 2005. Registration of three sunflower germplasms with quantitative resistance to race $\mathrm{F}$ of broomrape. Crop. Sci. 46: 1406-1407.

Pogorletsky, P.K. and Geshele, E.E., 1976. Sunflower immunity to broomrape, and rust. In: Proc. $7^{\text {th }}$ Int. Sunflower Conf., 27 June-3 July 1976. Krasnodar, Russia. Int. Sunflower Assoc., Paris. pp. 238-243.

Pustovoit, V.S., 1966. Selection, seed culture and some agrotechnical problems in sunflower. Translated from the Russian in 1976 by Indian National Scientific Documentation Centre (INSDOC), Delhi, India.

Ramaiah, K.V., 1987. Control of Striga and Orobanche species. A review. In: H.C. Weber, and W. Forstreuter (Eds). Parasitic Flowering Plants. Philipps-Universität, Marburg, Germany. pp. 637-664.

Rodríguez-Ojeda, M.I., Fernández-Escobar, J. and Alonso, L.C., 2001. Sunflower inbred line (KI-374) carrying two recessive genes for resistance against a highly virulent Spanish population of Orobanche cernua Loefl. / O. cumana Wallr. race "F". In: Proc. $7^{\text {th }}$ Int. Parasitic Weed Symposium, 5-8 June 2001. Nantes, France. pp. 208-211.

Ruso, J., Sukno, S., Domínguez-Giménez, J., Melero-Vara, J.M. and Fernández-Martínez, J.M., 1996. Screening of wild Helianthus species and derived lines for resistance to several populations of Orobanche cernua. Plant Dis. 80: 1165-1169.

Škorić, D., 1988. Sunflower breeding. Uljarstvo 25: 1-90.

Sukno, S., Melero-Vara, J.M. and Fernández-Martínez, J.M., 1999. Inheritance of resistance to Orobanche cernua Loefl. in six sunflower lines. Crop Sci. 39: 674-678.

Tang, S., Heesacker, A., Kishore, V.K., Fernández, A., Sadik, E.S., Cole, G. and Knapp, S.J., 2003. Genetic mapping of the Or5 gene for resistance to Orobanche race E in sunflower. Crop Sci. 43: 1021-1028.

Tolmachev, V.V., 1991. Identification of broomrape races and genes of sunflower resistance to the Moldavian race. In: Dragavcec, V.A. (Ed). Plant Growing, Genetics and Breeding of Industrial Crops. Collection of Scientific Works on Applied Botany, Genetics and Breeding. Leningrad, Russia. pp. 92-101.

Velasco, L., Pérez-Vich, B., Jan, C.C. and Fernández-Martínez, J.M., 2006. Inheritance of resistance to broomrape (Orobanche cumana Wallr.) race $\mathrm{F}$ in a sunflower line carrying resistance genes from wild sunflower species. Plant Breed. 126: 67-71.

Vrânceanu, A.V., Tudor, V.A., Stoenescu, F.M. and Pirvu, N., 1980. Virulence groups of Orobanche cumana Wallr. differential hosts and resistance sources and genes in sunflower. In: Proc. $9^{\text {th }}$ Int. Sunflower Conf., Torremolinos, Spain, 8-13 July 1980. Int. Sunflower Assoc., Paris. pp. 74-80.

\title{
ACTUALIZACIÓN DE LA SITUACIÓN DE LA MEJORA GENÉTICA DE GIRASOL PARA RESISTENCIA AL JOPO
}

\author{
RESUMEN
}

El jopo de girasol (Orobanche cumana Wallr.) está considerado en la actualidad como uno de los problemas mas importantes del cultivo de girasol (Helianthus annuus L.). En los últimos quince años, los esfuerzos realizados para incorporar fuentes de resistencia genética a este parásito en híbridos de girasol han estado acompañados por la rápida aparición de nuevas razas virulentas que superaban todos los genes de resistencia conocidos. Debido a esta situación, la mayoría de los esfuerzos de investigación se han centrado en el desarrollo y caracterización de nuevas fuentes de resistencia genética a las razas más virulentas del parásito, así como en la investigación de la estructura 
genética y variabilidad de las poblaciones de Orobanche cumana y de su evolución, con el objetivo de desarrollar estrategias duraderas a largo plazo para el control del jopo de girasol. Los resultados de evaluación de germoplasma de girasol para resistencia a diferentes razas han demostrado que las especies silvestres de Helianthus constituyen la mayor fuente de genes de resistencia a las nuevas razas virulentas. El germoplasma cultivado es también una valiosa fuente de genes de resistencia. La mayoría de las fuentes de resistencia están controladas por genes mayores, pero tanto resistencia cuantitativa como efectos epistáticos han sido también identificados. Se han observado diferentes reacciones de dominancia dependiendo de la raza de jopo, la fuente de resistencia y la línea utilizada como parental susceptible. Estudios moleculares han mostrado que la varianza fenotípica para la raza E se explica principalmente por un QTL mayor asociado con la resistencia o susceptibilidad del carácter, mientras que la resistencia a la raza $\mathrm{F}$ estuvo controlada por varios QTL de efecto pequeño o moderado asociados principalmente con el número de jopos por planta, lo que sugiere la existencia de un componente cuantitativo en la resistencia a la raza $\mathrm{F}$. Se discute la relevancia de estos resultados en la mejora para resistencia al jopo de girasol.

\section{MISE À JOUR DES ACTIONS DE SÉLECTION POUR LA RÉSISTANCE À L'OROBANCHE DU TOURNESOL}

RÉSUMÉ

L'orobanche du tournesol est couramment vue comme l'une des plus importantes contraintes de la production de tournesols. Ces 15 dernières années, des efforts pour introduire des sources génétiquement résistantes à ce parasite dans les hybrides de tournesol ont rapidement été suivis de l'apparition de nouvelles races virulentes qui sont venues à bout de tous les gènes de résistance connus. Au regard de cette situation, la majorité des efforts de recherche se sont concentrés sur le développement et la caractérisation de nouvelles sources de résistance génétique aux plus virulentes des races et aussi pour examiner la structure génétique et la variabilité des populations d'orobanches et leur évolution, afin de développer des stratégies à long terme, pour la gestion de l'orobanche du tournesol. Les résultats de l'évaluation de "germplasm" du tournesol pour la résistance aux diverses races a démontré que l'espèce sauvage d'helianthus constitue un le plus grand réservoir de gènes conférant une résistance aux nouvelles races virulentes. Les germplasms cultivés sont aussi une source valable de gènes résistants. La plupart des sources résistantes ont révélé être contrôlées par des gènes majeurs, bien que la résistance quantitative et les effets épistatiques aient été aussi reportés. Divers réactions de dominance, dépendant de la race d'orobanche, de la source de résistance, et de la susceptibilité de la lignée parentale utilisée pour le croisement ont été observées. Des études moléculaires ont montré que la variation du phénotype pour la résistance de la race $\mathrm{E}$ était principalement expliquée par une majeur QTL associée à la résistance ou au caractère susceptible, alors que la résistance de la race $\mathrm{F}$ était expliquée par divers QTL avec un effet de petit à modéré, principalement associé avec le nombre d'orobanche par plant, suggérant l'existence d'un composant en quantité dans la résistance à la race $\mathrm{F}$. La pertinence de ces constatations pour les cultures de tournesol résistantes à l'orobanche est discutée. 
